\title{
Investigation of applying calcium oxide for the removal of bitter substances from hop wastes
}

\author{
Krystyna Hoffmann, Józef Hoffmann, Marta Huculak-Mączka, Jakub Skut \\ Wroclaw University of Technology, Chemistry Department, Intitute of Inorganic Technology and Mineral Fertilizers, \\ ul. Wybrzeże Wyspiańskiego 27, 50-372 Wroctaw, Poland, e-mail: krystyna.hoffmann@pwr.wroc.pl
}

\begin{abstract}
Utilization of brewery wastes is one of the solutions for the production of the fodder supplements containing biogenic nutrients. The condition of such application is to meet the requirements included in the regulations regarding animal feeding, particularly removing a bitter taste. The aim of the performed investigations was the removal of bitter acids from the post-extraction hop waste using the calcium oxide addition. For the examination hop wastes obtained as a by-product from the $\mathrm{CO}_{2}$ plant extraction in supercritical conditions, were applied. Physicochemical properties of the waste samples collected for the investigations were determined by applying the available standard analytical techniques. The analyses of the determination of bitter acids were carried out by the high performance liquid chromatography method. During the experiments very good effects of bitter acids removal from hop wastes, were obtained by using $\mathrm{CaO}$ suspensions in water. The investigations on the influence of the $\mathrm{CaO}$ concentration in suspension on the efficiency of bitter acids removal indicate the possibility of applying suspensions by $2 \mathrm{wt} \%$ for this purpose.
\end{abstract}

Keywords: hop wastes, bitter acids, calcium oxide.

\section{INTRODUCTION}

Feeding the still increasing world population constitutes a great challenge for the modern science. It is connected with proper utilization of the natural resources, particularly soils, as well as with the requirement of the farm production intensification. Elimination of soils of the high quality for energy crops cultivation, observed particularly in Europe and the North America, cause deterioration of the situation in agriculture and animal breeding. It seems that preserving the principles of the Sustainable Development within this range, with the special stress put on the sustainability in the area of social economics, should gain the peculiar significance in the context of securing population with food supplies ${ }^{1-4}$.

Proper animal feeding requires supplying them with highly diversified nutrients like carbohydrates, lipids, proteins, amino acids, peptides, inorganic nitrogen compounds, mineral nutrients such as: calcium, phosphorus, magnesium, potassium, chlorine, sodium, sulfur, micronutrients and vitamins ${ }^{5}$.

Accepting the solutions enclosed in the principles of the Sustainable Development the examinations in the scope of wastes utilization are performed and modern technologies for the production of fodder supplements containing biogenic nutrients are developed ${ }^{6-8}$. Utilization of brewery wastes is one of the solutions mentioned above.

\section{WASTE PROPERTIES}

The post-extraction hop waste obtained from the production of bitter extracts under the method of their supercritical extraction was investigated. This waste on account of its composition is a valuable raw material which has potential applications in the fodders production. The condition of such application is to meet the requirements included in regulations regarding animal feeding, particularly removing the bitter taste 9

Four main raw materials are essential for the beer production: water, barley, hop and yeast.
Hop (Humulus Lupulus L.) in brewing relates to the "dried female fruit clusters (cones) and products obtained from them which contain hop components exclusively". Poland is the fifth largest hop producer on the world in terms of the surface area of the crops. According to the data from the year 2006, the hop was cultivated on the surface of about 2500 ha in about 1300 fields, the data from year 1996 show about 2480 ha, and this surface is constantly growing on account of increased beer consumption. The world hop demand reaches about 130000 t. On the territory of Poland hop is planted mainly in three areas: the region of Lublin, Wielkopolska province and Lower Silesia provinces. Mainly an aromatic and bitter hop are cultivated. For brewing applications particularly cones and lupuline-included hop resins are of great importance during hop-pickings.

The soft resin form contains first of all $\alpha$ and $\beta$-acids and imparting bitterness in the production of beer is most useful. The $\alpha$ and $\beta$-acids content is dependent on the hop variety. The insoluble in water $\alpha$-acids, called humulones, in the process of the wort production undergo a transformation into iso- $\alpha$-acids, giving the beer a characteristic bitter taste, and stabilizing the foam by the reduction of the surface tension. Under the influence of oxygen, temperature and humidity, the $\alpha$ and $\beta$-acids contained in lupuline undergo transformations resulting at the end of the process of beer manufacturing in the by-product formation in the hard resin form. Various substances are included in $\beta$-acids composition. The most important are the following ones: cohumulone - disadvantageous for its gustatory values, humulone and adhumulone. In the Bacids composition, the lupulone, colupulone and adlupulone can be observed. Individual bitter compounds demonstrate a different degree of bitterness. The iso- $\alpha$ acids demonstrate bitterness about 9 times stronger than the $\beta$ fraction $^{\mathbf{1 0}, \mathbf{1 1}}$.

The currently applied Magnum and Taurus hop varieties contain high contents of the $\alpha$-acids $(12-15 \% \mathrm{DM})$ including cohumulones concentration below $20 \%$ of the 
total amount of the $\alpha$-acids. The additional components of the lupuline, important for the brewing, are hop oils. Their content in the hop amounts from $0.5-1.2 \%$ DM. Hop oils are a mixture of about 250 volatile aromatic substances. The majority of oils is emitted during the wort boiling process. The sesquiterpenes play the most significant role in the characteristic beer aroma, on the other hand, myrcene has the adverse influence. On the account of volatile properties of oils, in the final phase of boiling the beer a small amount of aromatic hop is introduced. The other hop components are tannin agents. Their content in the hop amounts from $2-5 \%$ DM. They are complexed compounds of a high phenol functional group content (tannins, flavonols, catechins, anthocyanogens). They form complexes with proteins which are deposited at the bottom. They are responsible for a characteristic taste of the beer, its turbidity and the color. The proteins are highly valuable hop components $(12-20 \% \mathrm{DM})$. During the beer manufacturing process proteins are added in the amount of $30-50 \%$, the rest part remains in the hop wastes. In Poland a hop of $8-10 \%$ DM $\alpha$-acids contents of the name Lubelska (about 1000ha), Marynka (150ha) and Magnum (about 150ha) are the most frequently cultivated varieties.

From the research on the possibility of direct application of the post-extraction waste in fodders performed by the Wroclaw University of Environmental and Life Sciences it results that animals eat fodders, prepared by this method, reluctantly due to its bitter taste. Removing bitter acids using the organic solvents is possible, among them methanol belongs to the ones, used most often. However, taking toxicity into consideration, applying this method seems to be risky. Tests of the biodegradation of bitter hop acids through specific biological methods are also wellknown ${ }^{12}$.

The aim of the conducted investigations was the removal of bitter acids from the post-extraction hop waste, using the addition of the calcium oxide which has been already applied in the fodder industry.

\section{EXPERIMENTAL}

The hop applied in the beer production is most often in the processed form as a granulate or extract. For the examinations of hop wastes, originating from the installation launched by the Fertilizers Research Institute in Puławy, obtained as a by-product from the hop supercritically extracted with $\mathrm{CO}_{2}$, were applied ${ }^{\mathbf{1 3}, 14}$. A sample composition of hop wastes of the Marynka and Magnum hop varieties used in investigations was analyzed by the Division of Organic Synthesis in The Department of Chemistry of Wrockaw University of Environmental and Life Sciences. On average the hop wastes contained about $0.25 \mathrm{wt} \% \alpha$ and $\beta$-acids, $40 \mathrm{wt} \%$ cellulose and lignins, $15 \mathrm{wt} \%$ resins, $15 \mathrm{wt} \%$ proteins, $10 \mathrm{wt} \%$ water, 8 wt $\%$ ash, $4 \mathrm{wt} \%$ tanning agents. The composition of hop wastes indicates the contents of the components that can be used for production of balanced fodder.

\section{Methodology}

The investigation on the removal of $\alpha$ and $\beta$-acids from hop wastes was conducted on the laboratory scale. Every single time in the experiments, $5 \mathrm{~g}$ of hop wastes were weighed and treated in the conical flask of $250 \mathrm{ml}$ with an appropriate amount of $\mathrm{CaO}$ suspension of the concentration of $1 \mathrm{wt} \%, 2 \mathrm{wt} \%, 3 \mathrm{wt} \%, 4 \mathrm{wt} \%$ and $5 \mathrm{wt} \%$, respectively in order to preserve the mass ratio of hop wastes to suspension 1:20. The obtained solutions were mixed for 1 hour in the Unipan laboratory shaker at the mixing amplitude of 8 , at the external temperature of $20^{\circ} \mathrm{C}$. The phases were subsequently separated on the filters of the average time of filtration and next the phases were weighed. In the samples obtained from individual phases, appropriate analyses were carried out.

\section{Materials and methods}

The analyses of determination of $\alpha$ and $\beta$-acids were carried out by the Division of Organic Synthesis in The Department of Chemistry of Wrockaw University of Environmental and Life Sciences, applying the method of the liquid chromatography, with the use of Waters HPLC apparatus, equipped with 2690 modules and the 996 photodiode detector, adapted for a simultaneous determining of iso-alpha, alpha and beta acids, with the C-18 reversible column (Marcherey-Nagel, Nucleodur 100-5 C18, EC 250/4,6). The mobile phase consisted of 2 elements: A-methanol, B-MeOH: $\mathrm{H}_{2} \mathrm{O}: \mathrm{H}_{3} \mathrm{PO}_{4}$ :EDTA (so-

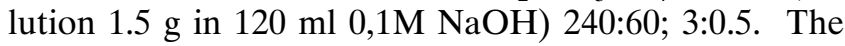
temperature of the column was $-28^{\circ} \mathrm{C}$. Portions of methanol solution were injected into the amounts 10 or $20 \mu \mathrm{l}$. The bitter acids content was determined at $270 \mathrm{~nm}$, by reading the data and calculating the contents on the basis of the calibration curve.

The water content was evaluated according to the PNZ_15011-33:2001 standard: Compost from municipal wastes was prepared, clause 3.2.3, by collecting a sample of the tested compound, earlier prepared, according to the PN-Z_15011-1:2001 standard, in the amount of 5g and drying it to constant mass in the laboratory drier at $105 \mathrm{oC}$.

The $\mathrm{pH}$ value was measured by the Mettler Toledo DL 50 titrator according to the operating manual of apparatus.

Determination of the contents of the organic matter was examined according to the PN-Z-15011-3:2001 standard, clause 3.2 - Compost obtained from municipal wastes. The method consists in determining the loss during the calcination at $500^{\circ} \mathrm{C}$. In examinations, on the basis of the literature data, regarding the fact that organic matter undergoes the combustion in the temperature range of $500-650^{\circ} \mathrm{C}$, a $650^{\circ} \mathrm{C}$ was applied. The remaining procedures were performed precisely according to the standard.

Determination of the organic carbon contents was conducted according to the PN-Z-15011-3:2001 standard: Compost obtained from municipal waste, clause 3.3. The method consists in the hot oxidation of the organic matter using the excess of $\mathrm{K}_{2} \mathrm{Cr}_{2} \mathrm{O}_{7}$ solution in the acidic environment, applying $\mathrm{Ag}_{2} \mathrm{SO}_{4}$ as the catalyst. $\mathrm{K}_{2} \mathrm{Cr}_{2} \mathrm{O}_{7}$ excess is titrated with Mohr's salt solution $\left(\mathrm{Fe}\left(\mathrm{NH}_{4}\right)_{2}\left(\mathrm{SO}_{4}\right)_{2} \cdot 6 \mathrm{H}_{2} \mathrm{O}\right)$ towards ferroine as the indicator.

Determination of the total nitrogen contents was performed according to the PN-93/C-87085 standard: Determining the total nitrogen contents using the distillation method. This method, the so-called Kjeldahl's method, consists in converting nitrogen to the ammonium form in the process of mineralization and the subsequent distilling of ammonia from the alkaline environment. Nitrogen 
in the distillation solution is determined by the titration method.

Examination of albuminous and ammonium nitrogen contents were conducted by applying the spectrophotometric method. This method consists in the degradation of the part of organic nitrogen using alkaline solution of the potassium permanganate. The ammonium nitrogen is distilled and analyzed spectrophotometrically before, and subsequently under the application of potassium permanganate in the alkaline environment the albuminous nitrogen is being released and distilled in the ammonia form. Nitrogen level is evaluated in the distillate using the spectrophotometric method ${ }^{\mathbf{1 5}}$.

The investigation of the total phosphorus contents was determined by applying the so-called "blue method", according to the PN-Z-15011-3:2001 standard: Compost obtained from municipal wastes. This method consists in sample incineration in the $650^{\circ} \mathrm{C}$ and subsequent mineralization of residues in the acidic environment. Phosphate ions are determined by the colorimetric method using ammonium molybdate in order to create phosphomolybdic acid. This acid is reduced by tin (II) chloride to phosphomolybdate-blue. Phosphorus is determined by spectrophotometer, at the wavelength of $690 \mathrm{~nm}$.

Total potassium was determined by the titration method according to the PN-91/C-87030/18 standard: Horticultural artificial fertilizers. Potassium was examined after prior mineralization of the samples according to the PNZ-15011-3:2001 standard. The base of the method consists in precipitating potassium with excess sodium tetraphenylborate (NaTPB). The excess of tetraphenylborate is subsequently titrated with cetyl trimethyl ammonium bromide (CTAB).

Calcium was determined according to the PN-90/C$87006 / 11$ standard, by applying the complexometric method, using disodium versenate, after prior mineralization of the samples according to the PN-Z-15011-3:2001 standard.

\section{RESULTS AND DISCUSSION}

For the examinations the hop wastes, originating from the installation applied by the Fertilizers Research Institute in Puławy, obtained as a by-product from the hop superctically extracted with $\mathrm{CO}_{2}$, were applied. The chemical composition of the waste samples collected for the investigations is presented in Table 1 .

The exemplary mass balance is shown in Table 2. It constitutes the basis for further calculations on the efficiency of $\mathrm{a}$ and $\mathrm{b}$ acids removal process.

The results of water content in the precipitates obtained during the investigated process are depicted in Table 3.

The $\alpha$ and $\beta$-acids content in the solution and precipitates was determined using the HPLC method (clause 2.9 of the report). Within the framework of examinations the following content were studied: $\alpha$-acids, cohumulone and $\mathrm{n}+$ adhumulone and $\beta$-acids, colupulone and $\mathrm{n}+$ adlupulone. Results were printed in Table 4 . The contents of iso-acids: iso-cohumulone, iso-humulone and isoadhumulone were presented in Table 5. The values of

Table 1. The physicochemical composition of hop wastes applied in the examinations

\begin{tabular}{|c|c|c|c|}
\hline No. & Name of compound & Unit & Examined compound content in raw hop wastes \\
\hline 1. & organic carbon Tiurin's method & $\mathrm{C}_{\text {org. }} \mathrm{wt} \%$ & 57.25 \\
\hline 2. & Organic matter thermal method $650^{\circ} \mathrm{C}$ & Org. matter wt\% & 90.92 \\
\hline 3. & total nitrogen & $\mathrm{N} w t \%$ & 3.21 \\
\hline 4. & aluminous nitrogen & $\mathrm{N}$ wt $\%$ & 2.93 \\
\hline 5. & ammonium nitrogen & $\mathrm{N}$ wt $\%$ & 0.796 \\
\hline 6. & total phosphorus & $\mathrm{K} w t \%$ & 1.770 \\
\hline 7. & total potassium & $\mathrm{P} w \mathrm{wt} \%$ & 0.075 \\
\hline 8. & calcium & Ca wt\% & 0.211 \\
\hline 9. & water $105^{\circ} \mathrm{C}$ & $\mathrm{H}_{2} \mathrm{O}$ wt $\%$ & 7.08 \\
\hline 10. & $1000^{\circ} \mathrm{C}$ - dry residue & $w t \%$ & 93.51 \\
\hline 11. & cohumulone & $w t \%$ & 0.0198 \\
\hline 12. & $\mathrm{n}+$ adhumulone & $w t \%$ & 0.0719 \\
\hline 13. & colupulone & $w t \%$ & 0.0065 \\
\hline 14. & n+adlupulone & wt\% & 0.0000121 \\
\hline 15. & total $\alpha$ and $\beta$ acids & wt\% & 0.0982 \\
\hline 16. & isocohumulone & $w t \%$ & 0.0080 \\
\hline 17. & isohumolne & wt\% & 0.0170 \\
\hline 18. & isoadhumulone & $w t \%$ & 0.00185 \\
\hline 19. & total iso-acids & wt\% & 0.02687 \\
\hline
\end{tabular}

Table 2. Exemplary mass balance of the process of hop wastes purification from $\alpha$ and $\beta$ acids by applying various CaO concentration in suspension

\begin{tabular}{|l|c|c|c|c|c|}
\hline \multirow{2}{*}{ No. } & \multirow{2}{*}{ Suspension concentration } & \multicolumn{2}{|c|}{ Input } & \multicolumn{3}{|c|}{ Output } \\
\cline { 2 - 6 } & & {$[\mathrm{wt} \%]$} & mass of raw hop wastes & mass of suspension & \multicolumn{2}{|c|}{ mass of precipitate } & mass of filtrate \\
\cline { 2 - 6 } & $1 \mathrm{wt} \% \mathrm{CaO}$ & 5.0016 & 99.9587 & 25.5251 & 79.4352 \\
\hline 2. & $2 \mathrm{wt} \% \mathrm{CaO}$ & 5.0135 & 99.3369 & 23.8721 & 80.4783 \\
\hline 3. & $3 \mathrm{wt} \% \mathrm{CaO}$ & 5.0191 & 99.5955 & 23.4302 & 81.1844 \\
\hline 4. & $4 \mathrm{wt} \% \mathrm{CaO}$ & 5.0224 & 99.7285 & 23.4302 & 79.1195 \\
\hline 5. & $5 \mathrm{wt} \% \mathrm{CaO}$ & 5.0111 & 99.6067 & 27.5199 & 77.0979 \\
\hline
\end{tabular}


Table 3. Water and dry matter content in the examined samples of hop wastes under the application of $\mathrm{CaO}$ suspension

\begin{tabular}{|c|c|c|c|c|}
\hline No. & Labelling & wt $\%$ mass loss at $60^{\circ} \mathrm{C}$ & wt $\% \mathrm{H}_{2} \mathrm{O} 100^{\circ} \mathrm{C}$ & wt $\%$ dry matter $100^{\circ} \mathrm{C}$ \\
\hline 1. & Solid phase $1 \% \mathrm{CaO}$ & 75.57 & 76.89 & 23.11 \\
\hline 2. & Solid phase $2 \% \mathrm{CaO}$ & 74.27 & 75.35 & 24.65 \\
\hline 3. & Solid phase $3 \% \mathrm{CaO}$ & 72.21 & 73.28 & 26.72 \\
\hline 4. & Solid phase 4 $\% \mathrm{CaO}$ & 68.32 & 69.46 & 30.54 \\
\hline 5. & Solid phase 5 $\% \mathrm{CaO}$ & 65.98 & 67.18 & 32.82 \\
\hline
\end{tabular}

Table 4. The results of $\alpha$ and $\beta$-acids contents [wt $\%$ ] in raw hop wastes, precipitates and filtrate after the purification process by applying $\mathrm{CaO}$

\begin{tabular}{|c|c|c|c|c|c|c|}
\hline \multirow[b]{3}{*}{ No. } & \multirow[t]{2}{*}{ Name of applied compound } & 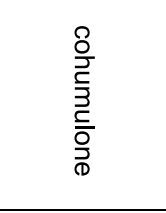 & 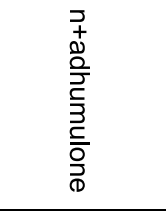 & $\begin{array}{l}\frac{8}{\frac{8}{5}} \\
\frac{0}{0} \\
\frac{\overline{0}}{0} \\
\frac{0}{0}\end{array}$ & 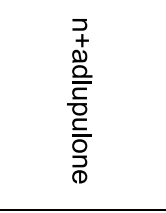 & Total $\alpha$ and $\beta$-acids \\
\hline & & \multicolumn{5}{|c|}{$[\mathrm{wt} \%]$} \\
\hline & Raw hop wastes & 0.019756 & 0.071898 & 0.006524 & 0.0000121 & 0.09819 \\
\hline \multicolumn{7}{|c|}{$\alpha$ and $\beta$-acids contents in the solid phase } \\
\hline 1. & $1 \mathrm{wt} \% \mathrm{CaO}$ & 0.00172 & 0.002418 & 0.013979 & below MDL & 0.018117 \\
\hline 2. & $2 \mathrm{wt} \% \mathrm{CaO}$ & 0.00657 & 0.002169 & 0.004985 & below MDL & 0.013724 \\
\hline 3. & $3 \mathrm{wt} \% \mathrm{CaO}$ & 0.0022 & 0.007103 & 0.000703 & below MDL & 0.010006 \\
\hline 4. & $4 \mathrm{wt} \% \mathrm{CaO}$ & 0.00064 & 0.00208 & 0.00031 & below MDL & 0.00303 \\
\hline 5. & $5 \mathrm{wt} \% \mathrm{CaO}$ & below MDL & below MDL & below MDL & below MDL & below MDL \\
\hline \multicolumn{7}{|c|}{$\alpha$ and $\beta$-acids contents in the liquid phase } \\
\hline 6. & $1 \mathrm{wt} \% \mathrm{CaO}$ & 0.00204 & below MDL & below MDL & below MDL & 0.00204 \\
\hline 7. & $2 \mathrm{wt} \% \mathrm{CaO}$ & 0.00034 & below MDL & below MDL & below MDL & 0.00034 \\
\hline 8. & $3 \mathrm{wt} \% \mathrm{CaO}$ & 0.00195 & below MDL & below MDL & below MDL & 0.00195 \\
\hline 9. & $4 \mathrm{wt} \% \mathrm{CaO}$ & 0.00205 & below MDL & below MDL & below MDL & 0.00205 \\
\hline 10. & $5 \mathrm{wt} \% \mathrm{CaO}$ & below MDL & below MDL & below MDL & below MDL & below MDL \\
\hline
\end{tabular}

Table 5. The results of iso-acids contents [wt\%] in raw hop wastes, precipitates and filtrate after the purification process by applying $\mathrm{CaO}$

\begin{tabular}{|c|c|c|c|c|c|}
\hline \multirow[b]{3}{*}{ No. } & \multirow[t]{2}{*}{ Name of applied compound } & 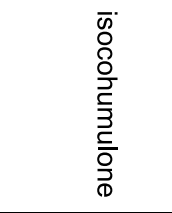 & 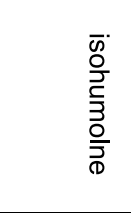 & 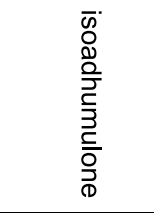 & Total iso-acids \\
\hline & & \multicolumn{4}{|c|}{ [wt \%] } \\
\hline & Raw hop wastes & 0.007991 & 0.017031 & 0.0018474 & 0.026869404 \\
\hline \multicolumn{6}{|c|}{ iso-acids contents in the solid phase } \\
\hline 1 & $1 \mathrm{wt} \% \mathrm{CaO}$ & 0.00494639 & 0.00538 & 0.0019143 & 0.01224069 \\
\hline 2 & $2 \mathrm{wt} \% \mathrm{CaO}$ & 0.0052188 & 0.00697 & 0.0015476 & 0.01373640 \\
\hline 3 & $3 \mathrm{wt} \% \mathrm{CaO}$ & 0.00387005 & 0.00213 & 0.0040099 & 0.01000995 \\
\hline 4 & $4 \mathrm{wt} \% \mathrm{CaO}$ & 0.00343336 & 0.00165 & 0.0033553 & 0.00843866 \\
\hline 5 & $5 \mathrm{wt} \% \mathrm{CaO}$ & 0.00122651 & 0.00079 & 0.0003413 & 0.00235781 \\
\hline \multicolumn{6}{|c|}{ iso-acids contents in the liquid phase } \\
\hline 6 & $1 \mathrm{wt} \% \mathrm{CaO}$ & 0.0054569 & 0.00383 & 0.0007066 & 0.0099935 \\
\hline 7 & $2 \mathrm{wt} \% \mathrm{CaO}$ & 0.0044364 & 0.00268 & 0.000770 & 0.0078864 \\
\hline 8 & $3 \mathrm{wt} \% \mathrm{CaO}$ & 0.0043322 & 0.00283 & 0.0005159 & 0.0076781 \\
\hline 9 & $4 \mathrm{wt} \% \mathrm{CaO}$ & 0.0039189 & 0.00268 & 0.0004874 & 0.0070863 \\
\hline 10 & $5 \mathrm{wt} \% \mathrm{CaO}$ & 0.0038267 & 0.00237 & 0.0005405 & 0.0067372 \\
\hline
\end{tabular}

hop wastes purification degree related to bitter acids removal were given in Table 6 . The elimination percentage of $\alpha$ and $\beta$-acids was calculated according to the following formula:

$$
\eta=\frac{\left(c_{i}-c_{f}\right)}{c_{i}} x 100[\%]
$$

where:

$\eta$-degree of removal of particular $\alpha$ or $\beta$ acid from raw hop waste during purification process, [\%] $c_{i}-$ particular $\alpha$ or $\beta$ acid content in raw hop wastes, [wt\%], [g]

$\mathrm{c}_{\mathrm{f}}-$ particular $\alpha$ or $\beta$ acid content in hop wastes after purification process, [wt $\%$ ], [g]

The content of the total $\alpha$ i $\beta$ acids (hop acids), albuminous nitrogen, loss of the dry mass in hop wastes after the purification process by applying $\mathrm{CaO}$, was a criteria of usefulness as a valuable animal fodders. The total content of $\alpha$ i $\beta$ acids in the raw hop wastes was $0.0982 \mathrm{wt} \%$. The best results of hop acids content in the hop wastes 
Table 6. The degree of hop wastes purification ( $\eta[\%]$ ) ragarding $\alpha, \beta$ and iso-acids under the application of CaO of various concentrations [wt\%]

\begin{tabular}{|c|c|c|c|c|c|c|}
\hline \multirow[b]{3}{*}{ No. } & \multicolumn{6}{|c|}{ The degree of bitter acids removal from hop wastes } \\
\hline & \multirow[t]{2}{*}{ Name of applied compound } & $\begin{array}{l}8 \\
\frac{8}{2} \\
\frac{1}{3} \\
\frac{c}{0} \\
\text { 잉 }\end{array}$ & 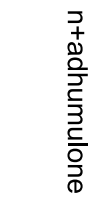 & $\begin{array}{l}\frac{8}{\frac{\delta}{2}} \\
\frac{0}{0} \\
\frac{\mathrm{C}}{0} \\
\frac{0}{0}\end{array}$ & 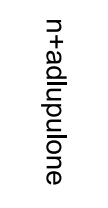 & Total $\alpha$ and $\beta$-acids \\
\hline & & \multicolumn{5}{|c|}{ [wt\%] } \\
\hline 1. & $1 \mathrm{wt} \% \mathrm{CaO}$ & 91.30 & 96.64 & 36.25 & 100.00 & 81.55 \\
\hline 2. & $2 \mathrm{wt} \% \mathrm{CaO}$ & 66.73 & 96.98 & 23.60 & 100.00 & 86.02 \\
\hline 3. & $3 \mathrm{wt} \% \mathrm{CaO}$ & 88.85 & 90.12 & 89.22 & 100.00 & 89.81 \\
\hline 4. & $4 \mathrm{wt} \% \mathrm{CaO}$ & 96.77 & 97.11 & 95.25 & 100.00 & 96.91 \\
\hline 5. & $5 \mathrm{wt} \% \mathrm{CaO}$ & 100.00 & 100.00 & 100.00 & 100.00 & 100.00 \\
\hline
\end{tabular}

Table 7. Total, ammonium and albuminous nitrogen contents in the samples after the application of CaO suspensions of various concentrations for bitter acids removal

\begin{tabular}{|c|c|c|c|c|c|c|c|}
\hline No. & Labelling & $\begin{array}{c}\text { Total } \\
\text { nitrogen } \\
\mathrm{N}_{\mathrm{t}} \\
\end{array}$ & $\begin{array}{l}\text { Total nitrogen } \\
\mathrm{N}_{\mathrm{t}} \text { by dry matter }\end{array}$ & $\begin{array}{l}\text { Albuminous } \\
\text { nitrogen } \mathrm{N}_{\text {alb. }} \text {. }\end{array}$ & $\begin{array}{l}\text { Albuminous nitrogen } \\
\mathrm{N}_{\mathrm{alb}} \text { by dry matter }\end{array}$ & $\underset{\text { nitrogen } \mathrm{N}_{\mathrm{NH} 4}^{+}}{\text {Ammonium }}$ & $\begin{array}{c}\text { Ammonium } \\
\text { nitrogen } \mathrm{N}_{\mathrm{NH}}{ }^{+} \text {by } \\
\text { dry matter }\end{array}$ \\
\hline & & \multicolumn{6}{|c|}{ [wt\%] } \\
\hline 1. & Solid phase $1 \% \mathrm{CaO}$ & 0.586 & 2.537 & 0.396 & 1.714 & 0.161 & 0.698 \\
\hline 2. & Solid phase $2 \% \mathrm{CaO}$ & 0.602 & 2.444 & 0.404 & 1.639 & 0.122 & 0.495 \\
\hline 3. & Solid phase $3 \% \mathrm{CaO}$ & 0.513 & 1.923 & 0.325 & 1.216 & 0.080 & 0.299 \\
\hline 4. & Solid phase $4 \% \mathrm{CaO}$ & 0.498 & 1.637 & 0.325 & 1.064 & 0.049 & 0.160 \\
\hline 5. & Solid phase $5 \% \mathrm{CaO}$ & 0.498 & 1.505 & 0.307 & 0.935 & 0.041 & 0.125 \\
\hline 6. & Liquid phase $1 \% \mathrm{CaO}$ & 0.093 & - & 0.050 & - & 0.009 & - \\
\hline 7. & Liquid phase $2 \% \mathrm{CaO}$ & 0.097 & - & 0.054 & - & 0.009 & - \\
\hline 8. & Liquid phase $3 \% \mathrm{CaO}$ & 0.096 & - & 0.056 & - & 0.007 & - \\
\hline 9. & Liquid phase $4 \% \mathrm{CaO}$ & 0.098 & - & 0.056 & - & 0.008 & - \\
\hline 10 & Liquid phase $5 \% \mathrm{CaO}$ & 0.095 & - & 0.052 & - & 0.009 & - \\
\hline
\end{tabular}

Table 8. The results of organic carbon contents in the precipitates and filtrates determined by Tiurin's method and in the precipitates of organic matter determined by the thermal method during the bitter acids elimination process from hop wastes applying $\mathrm{CaO}$ suspensions of various concentrations

\begin{tabular}{|c|c|c|c|c|c|}
\hline \multirow{3}{*}{ No. } & \multirow{3}{*}{ Labelling } & \multicolumn{3}{|c|}{ Solid phase } & \multirow{2}{*}{$\begin{array}{c}\text { Liquid phase } \\
\text { Tiurin's method } \\
\text { corg }_{\text {org }}\end{array}$} \\
\hline & & \multicolumn{2}{|c|}{$\begin{array}{c}\text { Tiurin's method } \\
\text { corg }_{\text {org }}\end{array}$} & \multirow{2}{*}{$\begin{array}{c}\text { Thermal method } 650^{\circ} \mathrm{C} \\
{[\mathrm{wt} \%]}\end{array}$} & \\
\hline & & {$[w t \%]$} & [wt\%] by dry matter & & {$[w t \%]$} \\
\hline 1 & $1 \mathrm{wt} \% \mathrm{CaO}$ & 12.86 & 55.65 & 96.41 & 0.32 \\
\hline 2 & $2 \mathrm{wt} \% \mathrm{CaO}$ & 12.85 & 52.14 & 94.62 & 0.37 \\
\hline 3 & $3 \mathrm{wt} \% \mathrm{CaO}$ & 6.27 & 23.48 & 92.78 & 0.38 \\
\hline 4 & $4 \mathrm{wt} \% \mathrm{CaO}$ & 4.94 & 16.17 & 91.52 & 0.41 \\
\hline 5 & $5 \mathrm{wt} \% \mathrm{CaO}$ & 3.96 & 12.07 & 85.56 & 0.48 \\
\hline
\end{tabular}

after bitter acids removal were obtained by using the 5 wt $\%$ suspension of $\mathrm{CaO}$. However, in the case of this $\mathrm{CaO}$ concentration it was connected with a relatively significant loss of protein. The content of protein in hop wastes after the process of purification from $\alpha$ i $\beta$ acids was determined by content of component of its decomposition (albuminous nitrogen). $2 \mathrm{wt} \%$ suspension of $\mathrm{CaO}$ was also a good reagent for bitter acids removal but this medium lets to recover high content of albuminous nitrogen. The obtaining the evidence of the protein decomposition is done by translocation profile of organic matter from solid to liquid phase during the process, what gives more beneficial results. Basing on their we can conclude that the proteins decomposition did not undergo totally and products of their degradation remained in the liquid phase
Ammonium and albuminous nitrogen concentration was determined in solution and precipitates. The results are printed in Table 7.

Otaining the evidence of the protein decomposition is done by the translocation profile of organic matter from the solid to liquid phase during the process, which gives more beneficial results. We can conclude that the proteins decomposition did not undergo totally and the products of their degradation remained in the liquid phase.

The results of organic carbon and organic matter contents determined by the Tiurin's method for the precipitates and liquid phase and the thermal method for the precipitates are shown in Table 8.

\section{SUMMARY AND CONCLUSIONS}

During the experiments very good effects of $\alpha$ and $\beta$ acids removal from hop wastes, gained after the produc- 
tion of hop extract, were obtained by using $\mathrm{CaO}$ suspensions in water. Investigations on the influence of the $\mathrm{CaO}$ concentration in suspension on the efficiency of bitter acids removal indicate the possibility of applying the suspensions by $2 \mathrm{wt} \%$ for this purpose. Any significant differences, excluding colupulone at low concentrations, as a result of individual bitter acids removal weren't observed

The parameter which determines the quality of fodders from applying hop wastes after bitter acids removal is the protein content. The results of the examinations of different nitrogen forms contents in hop wastes after the process of purification from $\alpha$ and $\beta$-acids, suggest that the suspensions of $\mathrm{CaO}$ up to the $2 \mathrm{wt} \%$ in the water change the albuminous nitrogen content to a small degree, which allows the conclusion that protein decomposition proceeds in a small degree.

More beneficial results, giving the evidence of the protein decomposition, were obtained using the translocation profile of the organic matter from the solid to liquid phase during the process. It is possible to conclude on their base that the proteins decomposition did not undergo totally and the products of their degradation remained in the liquid phase.

Summarizing the investigations it is possible to state that the suggested method of removing bitter acids from hop wastes is efficient and can be used in the fodder mixes manufacturing industry.

\section{LITERATURE CITED}

1. The final documents of United Nations Conference "Environmental and Development" Rio de Janeiro (1992). Top of Earth, IOS, Warszawa, 1998.

2. Kowalski, Z. (1998). The cleaner produtions as strategy of protection of natural environment, Mentor, Kraków (in Polish).

3. Hoffmann, J. \& Hoffmann, K. (2003). Sustainable development in the production of fertilizers, Przem. Chem., 82, 8-9 (in Polish).

4. Hoffmann, J.N. \& Radosiński, E. (2007). Environmental management concepts supported by information technology, Pol. J Chem. Tech., 4, 8-13. DOI: 10.2478/v10026-007-0080-1

5. Jamroz, D. (2001). Animal nutrition and feeds, vol.1, Wyd. Nauk. PWN, Warszawa.

6. Hoffmann, J., Hoffmann, K., Borowiec, M. \& Huculak M. (2009). Environmental aspects of feed phosphates production, Pol. J Chem. Tech., 11,1, 16-19. DOI: 10.2478/v10026009-0005-2

7. Hoffmann, J. \& Hoffmann, K. (2009). Study on the production of feed calcium phosphates with the use of concentratrated phosphoric acid, Przem. Chem., 88/5,450-453 (in Polish).

8. Pera, K. (2005). Waste recovery - technologies and the possibility of methodological basis for a comprehensive economic evaluation of non-waste technology, IGSMiE PAN, Kraków (in Polish).

9. Amended propos al for Directive of the European Parliament and Council on undesirable substances and products In Animals nutrition. (2001) Official Journal on the European Communities, 2001/C96E/35.

10. Pazera, T. \& Rzemieniuk, T. (1998). Brewing, Wyd. Szkol. i Pedagog., Warszawa.

11. Kunze, W. (1999). Technology Brewing and Malting, Wyd. Piwochmiel/ VLB, Berlin (in Polish).

12. Mączka, W., Anioł, M., Huszcza, E., Bartmańska A., Żołnierczyk A. \& Wawrzeńczyk, Cz. (2009). Higher plants- mediated degradation of hop bitter acids, Przem. Chem., 88/ 5, 509-511 (in Polish).

13. Best Available Techniques (BAT), (2005). Guidelines for the brewing industry, Ministry of Environmental Protection, Warszawa (in Polish).

14. Skowroński, B. \& Mordecka, Z. (2001). Polish installation for supercritical extraction of hops, Przem. Chem., 11, 521-523 (in Polish).

15. Hermanowicz, W., Dożańska,W., Dojlido, J. \& Kosiorowski, B. (1976). Physico- chemical researches on the water and sewage, Arkady, Warszawa (in Polish). 